\title{
Treatment of multiple facial fractures in air crash survivor
}

\section{Tratamento de múltiplas fraturas faciais em sobrevivente de acidente aéreo}

\section{Tratamiento de múltiples fracturas faciales en sobrevivientes de un accidente aéreo}

\begin{abstract}
Panfacial fractures are due to high-energy trauma, making the treatment of patients since the first visit is challenging. Generally, these involve soft tissue injuries, comminuted fractures and even fragment loss. In addition to this, the surgical approach to facial reconstruction through the fixation of bone fragments can be postponed due to the patient's clinical conditions, which can lead the treatment to a more complex condition due to the possibility of infection, poor union of bone fragments and tissue contraction. The aim of this study is to discuss the clinical case of high-energy trauma caused by an air accident, leading to multiple facial and body fractures. And in this way contribute to the extremely limited scientific literature on the subject, with such etiology and significant facial trauma.
\end{abstract}

Keywords: Oral and maxillofacial surgeons; Facial injuries; Fracture fixation; Open fracture reduction. 


\section{Resumo}

As fraturas panfaciais são decorrentes de traumas de alta energia, tornando o tratamento dos pacientes desde a primeira consulta um desafio. Geralmente, envolvem lesões de tecidos moles, fraturas cominutivas e até mesmo perda de fragmentos. Além disso, a abordagem cirúrgica da reconstrução facial por meio da fixação de fragmentos ósseos pode ser postergada devido às condições clínicas do paciente, o que pode direcionar o tratamento a um quadro mais complexo pela possibilidade de infecção, má consolidação dos fragmentos ósseos e contração do tecido. O objetivo deste estudo é discorrer sobre o caso clínico de um paciente que sofreu trauma de alta energia causado por acidente aéreo, levando a múltiplas fraturas faciais e corporais. E desta forma contribuir para a literatura científica extremamente limitada sobre o assunto, com tal etiologia e traumas faciais significativos.

Palavras-chave: Cirurgiões bucomaxilofaciais; Traumatismos faciais; Fixação de fratura; Redução aberta.

\section{Resumen}

Las fracturas panfaciales se deben a traumatismos de alta energía, lo que dificulta el tratamiento de los pacientes desde la primera consulta. Suelen implicar lesiones de tejidos blandos, fracturas conminutas e incluso pérdida de fragmentos. Además, el abordaje quirúrgico de la reconstrucción facial mediante la fijación de fragmentos óseos puede retrasarse debido a las condiciones clínicas del paciente, lo que puede derivar en un tratamiento más complejo por la posibilidad de infección, mala consolidación de los fragmentos óseos y contracción del hueso tela. El objetivo de este estudio es discutir el caso clínico de un traumatismo de alta energía provocado por un accidente aéreo que provocó múltiples fracturas faciales y corporales. Y de esta manera contribuir a la literatura científica extremadamente limitada sobre el tema, con tal etiología y traumatismos faciales importantes.

Palabras clave: Cirujanos oromaxilofaciales; Traumatismos faciales; Fijación de fractura; Reducción abierta.

\section{Introduction}

Maxillofacial trauma generated by high-energy impact results in highly dislocated and/or comminuted facial fractures, creating a major challenge for oral and maxillofacial surgeons. When these happen, the patient must first be hemodynamically stabilized and airway control according to Advanced Trauma Life Support (Christensen, Sawatari \& Peleg 2015).

High-energy traumas are defined as open or closed injuries, caused by extreme forces and leading to severe tissue trauma. They are often associated with soft tissue damage and loss of bony structures, which can result in severe deformities. Multiple facial fractures, complex neurological trauma and airway impairment can be expected. In such cases, the treatment of facial fractures may need to be delayed, leading to osseous mal union, soft tissue contracture and scarring, delivering a poor functional and aesthetic outcome (Moreira, 2017).

When a first approach is necessary, surgical debridement is performed to remove comminuted bone fragments of inadequate sizes for fixation and the fragments that have soft tissue support and acceptable vitality are preserved (Stefanopoulos, et al., 2015). Several management schemes have been reported, including delayed and early surgical interventions. Such schemes usually consider patients clinical condition, bone remaining structure and remaining soft tissue quality.

\section{Methodology}

This clinical case report is part of a descriptive observational study, which in addition to discussing the proposed treatment, also aimed to discuss the topic through the bibliographic survey carried out (Pereira, et al., 2018). And thus contribute to the scarce scientific literature on the subject. Thus representing a descriptive and qualitative content.

The case was conducted according to clinical and professional ethics. The patient reported in the study has a personal data sheet and anamnesis, where he authorized the use of images, clinical, radiographic and socioeconomic data for educational and research purposes, and with this signed a Free and Informed Consent Form and the Informed Consent Form. Consent of the Person's Participation as a Subject, which were duly read and explained. 


\section{Case Report}

A 47-year-old man was victim of airplane accident in the Amazon forest being the only survivor of 5 crew in February 2018. The patient received the first care in the local and referred to the local hospital in Manaus, Amazon - Brazil presenting score 9 in Glasgow coma scale followed by intubation and sedation.

Computed tomography (CT) images showed right frontal brain hematoma with herniation to the right orbit as well as complex fractures in the mid face including bilateral orbito zygomatic fractures, bilateral orbital floor, right medial orbital wall, bilateral naso-orbit-ethmoid type 1 and a Le Fort I fracture with Lannelongue variation (Figure 1).

Bilateral hemothorax was diagnosed and drained in the emergency room. In addition other fractures were also diagnosed including right acetabulum, bilateral hummer and vertebral fractures in L1, L2, L3, L4 and L5.

Figure 1. a) 3D CT Reconstruction preop. b) CT preop scan.
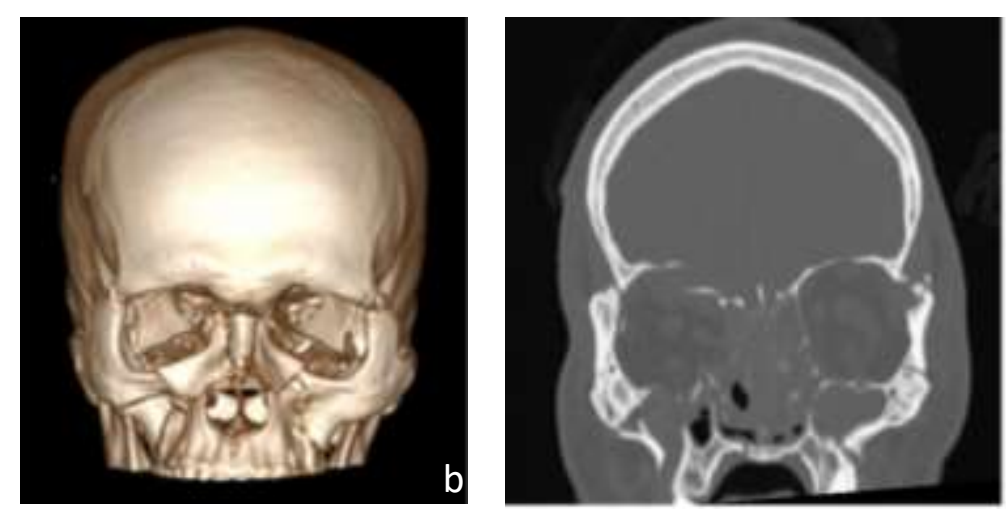

Source: Authors.

Because of the severity of the case, the patient was transferred to the Leforte Hospital in São Paulo - Brazil around 3.881 $\mathrm{Km}$ of distance by airplane equipped with intensive care unit. After arriving in the hospital, the patient was referred to the surgical room and the intubation was changed to the submental region and followed to the operation by the neurosurgery team. By a coronal approach, the frontal bone was osteotomized in the right side to decompress the hematoma on the brain (Figure 2a).

After this, the maxillofacial team started the surgical procedure approaching the orbital floors by subciliary incisions and the maxillary bone by intraoral incision. The bilateral frontal-zygomatic suture was fixed with $1.5 \mathrm{~mm}$ plate to reduce the sphenozygomatic suture to recover the three dimensional malar bone position, at this moment the zygomatic arches were also reduced and fixed with $2.0 \mathrm{~mm}$ system plates (Figure $2 \mathrm{~b}$ and $2 \mathrm{c}$ ). 
Figure 2. a) Coronal approach for hemantoma decompression. b) Approach to fixing the frontal-zygomatic and zygomatic arch. c) Nasal region and fronto- zygomatic suture fixed. d) Maxillary access and fixation. e) Subciliary access for reduction and reconstruction of the orbital floor. f) Nasal region fixed.
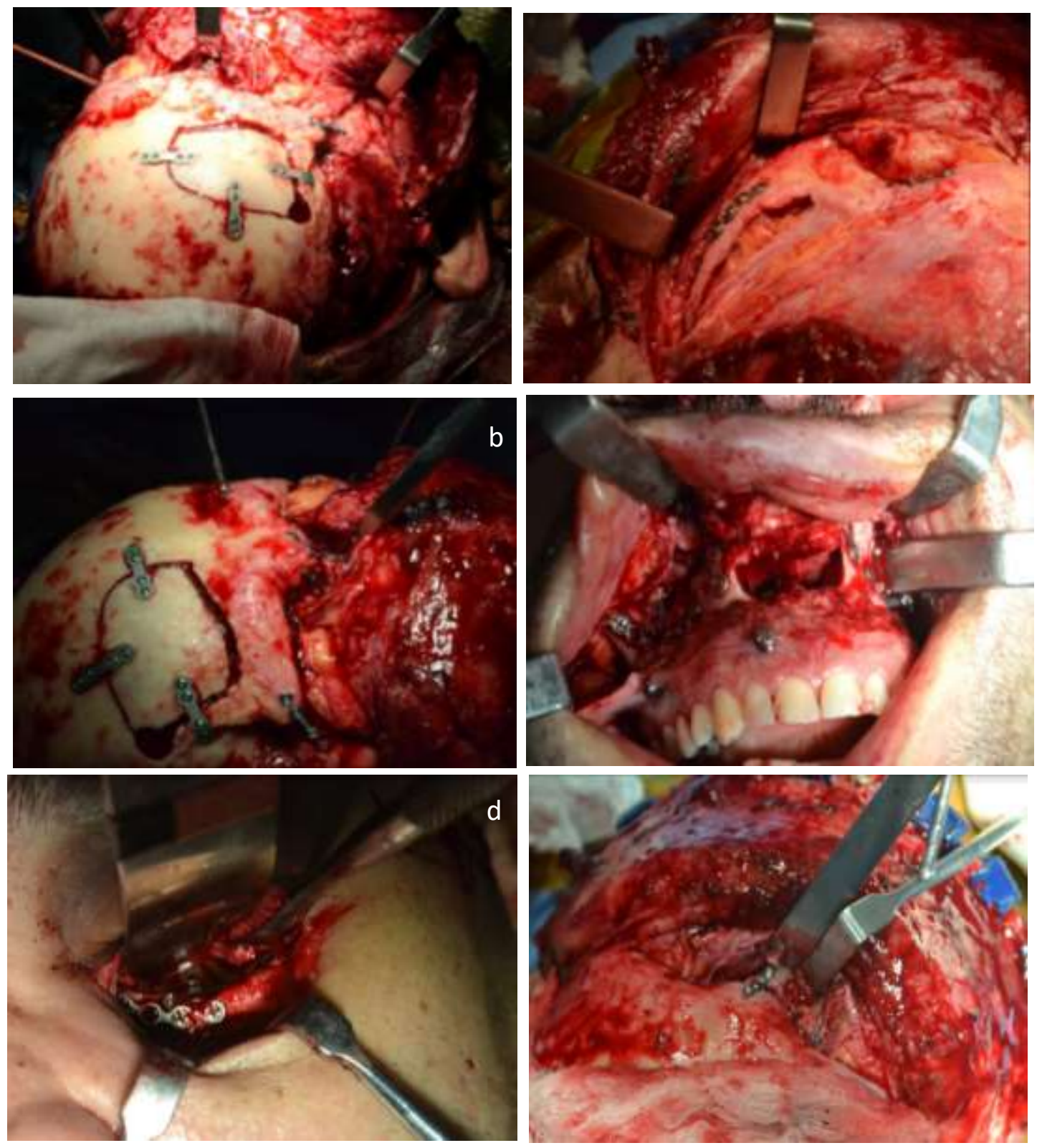

Source: Authors.

Then, the maxilla-mandibular fixation was performed with locking screws and then the zygomatic-maxillary fixation with $2.0 \mathrm{~mm}$ system plates was performed (Figure 2d). After the reestablish of occlusion and anterior-posterior dimension of the face, the central part of midface was reduced by both frontal-maxillary buttress fixations with two $2.0 \mathrm{~mm}$ plates and two $1.5 \mathrm{~mm}$ plates by subciliary approach (Figure 2e). The nasal bone was fixed with $1.5 \mathrm{~mm}$ plate and the bilateral orbital floor were reconstructed using $1.5 \mathrm{~mm}$ titanium mashes as well as the right medial orbital wall (Figure 2f). 
After the surgical intervention, the patient showed good projection of the facial thirds, restricted eye movement, without functional and aesthetic complaints (Figure 3a and 3b).

Figure 3. a) CT in the immediate postoperative period. b) 3D CT Reconstruction posop.
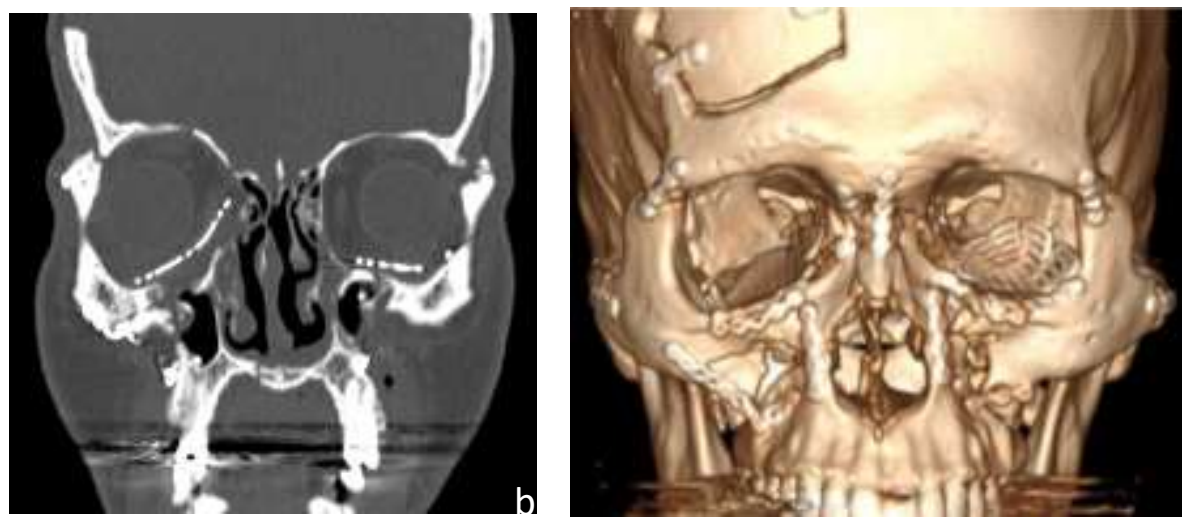

Source: Authors.

\section{Discussion}

High energy traumas represent a major challenge for the surgeon, presenting soft and hard tissue injuries such as avulsion, crushing and a jeopardized relationship between facial structures. Traditionally, these patients were treated in a conservative manner, with external fixation, soft tissue debridement and postponed reconstruction. Commonly, such protocols would achieve poor results due to inadequate bone reduction, soft tissue collapse and scarring.

A study conducted in the USA on the pattern and nature of injuries to people involved in air crashes was obtained by analyzing the Federal Aviation Administration's autopsy database for pilots involved in fatal helicopter accidents from 1993 to 1999. In this study, 84 autopsies were analyzed, revealing that closed trauma was cited as the main cause of death in $88.1 \%$ of these cases. The most common bone injuries were fractures of the ribs (73.8\%), skull (51.2\%), facial bones (47.6\%), tibia (34.5\%), thorax (32.1\%) and pelvis (31.0\%). Common organic/visceral lesions included brain (61.9\%), pulmonary (60.7\%), liver (47.6\%), heart (41.7\%), aorta (38.1/) and spleen (32.1\%). The patterns of injury did not seem to be related to the age of the pilot or to the flight phase (Taneja \& Wiegmann, 2013).

Thus, early reconstruction is recommending in such patients to achieve better functional and aesthetic results. Where understanding the distribution of strength through facial bones, evaluation of computed tomography images, graft techniques and semi-rigid fixation are essential to reestablish bone structure.

High-energy trauma to the face usually causes comminuted facial fractures. In these types of trauma, nasal and orbital fractures occur in conjunction with Le Fort fractures (Kaufman, Cole \& Hollier, 2009; Cillo \& Ellis, 2014; Stuehmer, et al., 2009). The facial skeleton bone pillars are able to absorb a significant amount of force, if the direction of this force originates in the lower part and runs along its lines. However, these columns are easily fractured when forces are perpendicular. (Pappachan \& Alexander, 2012) The significant damage to soft and hard tissues occurs according to the intensity of kinetic energy. The most common subgroups of high-energy trauma facial injuries can be classified as gunshot wounds and motor vehicle collision, and the most common facial fractures in these types of trauma are nasal, orbital, maxillary, zygomatic and mandibular bones (Stuehmer, et al, 2009; Peltola, Koivikko \& Koskinen, 2014; Chrcanovic, 2012). 
These traumas require special care in the surgical approach, it is necessary to understand the architecture of the face to initiate the reduction of fractures correctly to return to the patient the ideal projections and do the utmost to minimize sequelae and deformities. Surgical correction of zygomatic arch fractures is of great importance in the treatment of complex midface fractures. The zygomatic arch is of great importance in the anteroposterior positioning of the face and in maintaining facial width after complex fractures. Incorrect positioning of the zygomatic arch is one of the main causes of unsatisfactory results in this type of fracture and compromises the position of all other facial structures (Ribeiro, et al., 2015).

Fractures involving the naso-orbital-etmoid region (NOE) are among the most complete, being classified as Type I, II, III. Type I: when there is only one central fragment with the cantal ligament; Type II: when there is central segment comminuted with the medial cantal ligament still attached to the bone fragment; Type III: when there is central fragment comminuted with total detachment of the medial cantal ligament. Late treatment of this type of fracture may result in secondary deformities, including a shortened and retruded nose, enophthalmia, telecanthus and ocular dystopia. Diagnosis is based on clinical and imaging exmonitoring by means of computed tomography (Wei, et al, 2015).

Some studies have reported that both the mandible (Glapa, et al., 2007; Cohen, Shakenovsky \& Smith, 1986) and the zygoma (Hollier, Grantcharova \& Kattash, 2001) are the most commonly injured facial bones in high-intensity trauma. The most prominent bones are more likely to suffer injuries; thus, the nasal bones present a high fracture index, followed by the malar bone, orbit and mandible. The frontal bone is the most resistant to facial trauma (Pappachan \& Alexander, 2012)

Treatment of multiple facial fractures might be challenging. Several management sequences have been reported, including "bottom to top" or "top to bottom" and "inside-out" or "out-inside", usually considering where the surgeon is able to find reliable osseous references. The treatment plan must contemplate the need of bone grafts and soft tissue coverage.

\section{Conclusion}

Air accidents cause high-impact trauma, which shows us how important it is the presence of a trained oral and maxillofacial surgeon with experience in complex facial fractures to perform the appropriate approach and treatment for survivors in this type of accident. At the presented case, the high energy trauma had an unusual etiology, survivors from aircraft accidents are rare and presents as multiple trauma victims, which impairs the immediate reconstruction of facial fractures, late treatment as in this case makes treatment challenging.

We understand the rarity and severity of air accidents, but the authors suggest that whenever possible cases are reported on the topic so that in the future it is possible to better understand and describe the behaviors facing this fatality.

\section{References}

Chrcanovic, B. R. (2012). Factors influencing the incidence of maxillofacial fractures. Maxillofac Surg, $16(1), 3-17$.

Christensen, J., Sawatari, Y., \& Peleg, M. (2015). High-energy traumatic maxillofacial injury. J Craniofac Surg, 26(5), 1487-91.

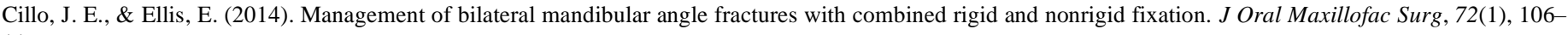
11.

Cohen, M. A., Shakenovsky, B. N., \& Smith, I. (1986). Low velocity hand-gun injuries of the maxillofacial region. J Maxillofac Surg, 14(C), 26-33.

Glapa, M., Kourie, J. F., Doll, D., \& Degiannis, E. (2007). Early management of gunshot injuries to the face in civilian practice. World J Surg, 31(11), 2104-10.

Hollier, L., Grantcharova, E. P., \& Kattash, M. (2001). Facial gunshot wounds: A 4-year experience. J Oral Maxillofac Surg, 59(3), $277-82$.

Kaufman, Y., Cole, P., \& Hollier, L. (2009). Facial Gunshot Wounds: Trends in Management. Craniomaxillofacial Trauma Reconstr, 2(02), 085-90. 
Research, Society and Development, v. 10, n. 1, e46410111919, 2021

(CC BY 4.0) | ISSN 2525-3409 | DOI: http://dx.doi.org/10.33448/rsd-v10i1.11919

Moreira, R. W. F. (2017). O tratado de Cirurgia Bucomaxilofacial. Nova Odessa- SP- Brasil: Editora Napoleão.

Pappachan, B., \& Alexander, M. (2012). Biomechanics of Cranio-Maxillofacial Trauma. J Maxillofac Oral Surg, 11(2), 224-30.

Peltola, E. M., Koivikko, M. P., \& Koskinen, S. K. (2014). The spectrum of facial fractures in motor vehicle accidents: An MDCT study of 374 patients. Emerg Radiol, 21(2), 165-71.

Pereira, A. S., et al. (2018). Metodologia da pesquisa científica. Ed. UAB/NTE/UFSM. https://repositorio.ufsm.br/bitstream/handle/1/15824/Lic_C omputacao_Metodologia-Pesquisa-Cientifica.pdf?sequence=1.

Ribeiro, A. L., Rodrigues, T. M., Alves-Junior, S. M., \& Pinheiro, J. J. (2015). Interfragmentary screw fixation of the zygomatic arch in complex midface and zygomaticomaxillary fractures. J Oral Maxillofac, 3(3), 494-8.

Stefanopoulos, P. K., Soupiou, O. T., Pazarakiotis, V. C., \& Filippakis, K. (2015). Wound ballistics of firearm-related injuries - Part 2: Mechanisms of skeletal injury and characteristics of maxillofacial ballistic trauma. Int J Oral Maxillofac Surg, 44(1), 67-78.

Stuehmer, C., Blum, K. S., Kokemueller, H., Tavassol, F., Bormann, K. H., Gellrich, N. C., et al. (2009). Influence of Different Types of Guns, Projectiles, and Propellants on Patterns of Injury to the Viscerocranium. J Oral Maxillofac Surg, 67(4), 775-81.

Taneja, N., \& Wiegmann, D. A. (2003). Analysis of injuries among pilots killed in fatal helicopter accidents. Aviat Space Environ Med, 74(4), 337-41.

Wei, J. J., Tang, Z. L., Liu, L., Liao, X. J., Yu ,Y. B., \& Jing, W. (2015). The management of naso-orbital-ethmoid (NOE) fractures. Chin J Traumatol, 18(5), 296301 . 